\title{
THE FUTURE OF THE EUROZONE: TOWARDS A EUROPEAN BENCHMARK ${ }^{1}$
}

\author{
CASAGRANDE, Sara* \\ DALLAGO, Bruno
}

Department of Economics and Management, University of Trento, Italy. *Correspondence to (sara.casagrande@unitn.it)

\section{COPYRIGHT NOTICE:}

\section{CITE THIS PAPER:}

Casagrande, Sara; \& Dallago, Bruno (2022). "The Future of the Eurozone: Towards a European Benchmark" Journal of World Economy: Transformations \& Transitions (JOWETT) 1(03):14. DOI: https://doi.org/10.52459/jowett13140122

\begin{abstract}
The European sovereign debt crisis has demonstrated the need for a rethinking of the European Integration Project. The strong variety between member countries prevented the Eurozone to become a fiscal and political union and the asymmetric architecture of the European Monetary Union (EMU) revealed different weaknesses. The outbreak of the Covid-19 emergency may represent a turning point for the EU and makes even more evident that the future of the Eurozone will depend also on the ability of member countries to make their institutional frameworks coexist. Helping member countries to achieve sustainable and stable outcomes, although in idiosyncratic ways, is the task of the European benchmark. It is a framework, inspired by European treaties, that aims to identify inefficiencies in terms of market, state and social failures and negative externalities inside economic, social, and political institutions. This benchmark represents a new tool for a correct evaluation of the economic, social, and political performance of the European member countries.
\end{abstract}

\section{KEYWORDS}

Benchmark, European Economic Integration, European Sovereign Debt Crisis, Eurozone, Institutional Variety.

\footnotetext{
${ }^{1}$ A non peer-reviewed version of this article was published as TIGER Working Paper Series No. 143, Warsaw, February 2021 (http://tiger.edu.pl/publikacje/working.htm ).
} 


\section{INTRODUCTION}

The European sovereign debt crisis has demonstrated the need for a rethinking of the institutional architecture at the base of the European Union (EU) project. The strong institutional variety between member countries prevented Eurozone to become a fiscal and a political union. The asymmetric architecture of the European Monetary Union (EMU), which implies a common monetary policy but national fiscal policies, revealed different weaknesses. Indeed, the same macroeconomic policies that were appropriate for some countries were revealed to be dysfunctional for others. Macroeconomic imbalances have made some European countries particularly vulnerable to financial market turmoil. The financial crisis has overwhelmed the governments of the most exposed countries endangering the solidity of the Eurozone.

The outbreak of the Covid-19 emergency may represent a turning point for the EU. In this paper, it will be sustained that are not institutional and economic differences that threaten the future of the Eurozone but, among other things, the inefficiencies in their economic, social, and political institutions. Rather than promoting institutional convergence, European institutions should help member countries to make their institutional frameworks work better and coexist, by implementing responsible policies, avoiding moral hazard and non-cooperative attitudes, ensuring stability and soundness, and avoiding negative spillovers.

It will be proposed a European benchmark $(\mathrm{Eb})$, inspired by European treaties, as a new tool for a correct evaluation of the economic, social, and political performance of the European member countries. Its purpose is to help member countries to identify inefficiencies in terms of market, state and social failures and externalities inside economic, social, and political institutions. It aims to help member countries to achieve efficient, sustainable, and stable outcomes, although in idiosyncratic ways.

In section 2, the role of the institutional variety in the European project, the integration process and during the crisis will be discussed. In section 3, the concept of Eb will be presented and its pillars will be defined. Section 4 contains the research conclusions.

\section{THE EUROZONE BETWEEN INTEGRATION AND CRISIS}

\subsection{Institutional variety in the European project}

The experiences of the world wars have led many European policy-makers to consider it essential to promote a European integration process (Maes, 2002; Dyson, 2000). However, the institutional and cultural variety that characterizes Europe, has certainly contributed to making fiscal and political union an objective that may have been achievable only in the long run. An economic and monetary union was therefore carried out, in the hope that it could represent a spur to reach a fiscal and political union. 
Some scholars have questioned the democratic legitimacy of the European integration project (Follesdal and Hix, 2006) and have highlighted the danger of putting monetary and economic union before the political and fiscal union (e.g., Kaldor, 1980). Despite these criticisms, many scholars hoped that the possible disadvantages of EMU asymmetric architecture could have been mitigated by progressive economic and institutional convergence. Some scholars sustained the possibility of an ex-post economic convergence. In particular, according to the literature on endogenous Optimal Currency Area (OCA) analysis, "a country is more likely to satisfy the criteria for entry into a currency union ex-post than ex-ante" (Frankel and Rose, 1998, p.1024).

The OCA debate related to the European monetary integration did not reach a final consensus. It is worth remembering that despite OCA theory has been regarded as the «theoretical core of the Euro Zone» (Dan, 2014, p.72), «the optimum currency area argument has been used both for and against the creation of the euro» (Vane and Mulhearn, 2006, p.98). According to the OCA theory pioneered by Mundell (1961) and McKinnon (1963), economically similar countries which are part of the same geographic area would benefit from the introduction of a single currency only under certain conditions (e.g., price and wage flexibility, high labour and capital mobility, analogous shocks, similar business cycles etc). The countries that intended to form the Eurozone satisfied only partially these conditions. While endogenous OCA analysis has been used to sustain the idea that monetary integration would have induced economic and political convergence at least in the long run and was fundamentally the position of the European Commission, the traditional OCA theory has been used to sustain the necessity to ensure political and economic convergence before monetary integration (see Dyson and Maes, 2016 for more details). In this debate, the first viewing has gained ground thanks to the support of the growing literature on globalization, which foresees that in a global economy the competition among advanced economies would have induced them to converge towards the liberal model, the one considered most efficient.

With particular reference to the European case, some scholars interpreted Europeanization as an amplifier of globalization because it would faster the convergence towards the Anglo-Saxon model (Streeck, 1997; Windolf, 1989). The neoliberal influence on the Europeanization process seemed quite significant, although this vision has been criticized (Cernat, 2006). Indeed, according to some scholars, the deregulated neoliberalism of the Anglo-Saxon model and the social democratic corporatism of the Continental model can coexist (Calmfors and Driffill, 1988; Hall and Soskice, 2001) and empirical evidence seems to testify the persistence of national divergences (Blaschke, 2000). Beyond this, Willett et al. (2010, p.851) sustain that "those who favour a currency union, dollarisation, or some other form of hard fix may exaggerate the degree of endogeneity and some have gone so far as to suggest that almost any currency union can become optimal ex-post". Many scholars within the Varieties of Capitalism (VoC) theory states that advanced capitalist economies will not converge towards a single liberal type because of the comparative institutional advantage from different socio-economic models (Hall and Soskice, 2001). 


\subsection{An uneasy integration process: the crisis and the European troubles}

Despite the initial enthusiasm, even before the outbreak of the crisis, there had emerged a growing discontent among the European population towards the EMU, as documented by Marsh (2009). These disagreements seemed to be justified by unsatisfactory economic performance and worrisome imbalances.

The evolution of the European integration process seemed to demonstrate that a certain degree of economic convergence does not imply, however, political, or cultural convergence. Institutional convergence within the EU is far more problematic than economic convergence (Schönfelder and Wagner, 2019). Alesina et al. (2017) note that better results were achieved in terms of convergence from an economic point of view rather than at an institutional and cultural level and identify in national identities the factor that most hinders deeper integration.

Faced with the financial crisis in 2007 and even more with the European sovereign debt crisis, EMU architecture showed all its weaknesses. The presence of a monetary union without a fiscal union was revealed to be a "design failure" (De Grauwe, 2013), as feared by some scholars. Some of them talked about the existence of a trilemma for the Eurozone, i.e., the impossibility to carry on a monetary union with fiscal sovereignty and no-bailout clause (Beck and Prinz, 2012). Given European economic and institutional variety, the common currency implied that "the interaction between macroeconomic policies and national institutions works very differently for different parts of the union, rendering policies that are appropriate for southern Europe dysfunctional for northern Europe, and vice versa" (Iversen and Soskice, 2013, p.2). During the crisis, the consequences for European member countries to have given up their monetary sovereignty without a fiscal union have become evident. Indeed, as noted by Thirion $(2017$, p.8) "the rise in public debt due to a shock cannot be reversed through devaluations", moreover, "lacking a budget backed by lender-oflast-resort guarantees, i.e. a central bank, speculators are systematically able to exacerbate fiscal troubles in weak countries, driving up sovereign risk premia to potentially unsustainable levels".

The strategies adopted by the European institutions to tackle the sovereign debt crisis are well known. The countries most damaged by the crisis were invited to respect the Maastricht criteria through compliance with strict fiscal discipline, austerity measures and structural reforms. The European institutions have always considered the member countries' behaviour as the main source of the crisis, in light of their violations of the fiscal discipline and their reluctance to apply the necessary but unpopular structural reforms. As confirmed by Scharpf (2011, p.189), "there is no acknowledgement in any of the supporting documents of the role that uniform ECB interest rates played in causing macroeconomic imbalances among the heterogeneous member economies of a 'non-optimal currency area'".

Certainly, with the worsening of the crisis, the European institutions have tried to adapt their policies by considering more carefully social issues and countries heterogeneity. For example, the European Semester introduced in 2011, represented an important novelty among European policies. It is often claimed that it 
improved the coordination of economic and fiscal policies and overcame the one size fits all approach through its country-specific recommendations based on detailed country reports. With its "growing emphasis on social objectives" (Zeitlin and Vanhercke, 2017, p.167), it seems to consider really the role of institutional variety and social issues. However, not everyone shared the same enthusiasm. According to D'Erman et al. (2019, p.196), the European Semester "builds on the economic rules that had been in place since the start of EMU and have been further developed in EMU's first decade. These include the so-called Stability and Growth Pact (SGP) that was already developed early on but also the Macroeconomic Imbalance Procedure (MIP) introduced in 2011". Moreover, "the policy areas affected by a recommendation are mostly a proxy for the EU's reform priorities; in and by themselves they do not tell us much about how exactly the EU is trying to alter the policies of a member state within a given policy area" (p.206). In addition to this, "as noted by several authors, the slippage of Europe 2020 into the European Semester since 2011-12 has meant the further absorption of social policy into macroeconomic policy, and the political focus has clearly been placed on budgetary oversight and deficit reduction" (Crespy and Menz, 2015, p.762).

\subsection{Which model for Europe? Varieties of capitalism in Europe}

One of the problems that seems to have persisted also in the following years after the outbreak of the European sovereign debt crisis is the lack of a real strategy to recover the growth prospects. In spite of everything, fiscal discipline and structural reforms aimed to induce a convergence towards more flexible and liberal markets, remain the fundamental pillars of the strategy of the European institutions, as confirmed by the European Commission's EMU@10 report in 2008, the report A blueprint for a deep and genuine economic and monetary union - Launching a European Debate in 2012, the various Memorandum of Understanding, the European Semester, the fiscal compact up to the Reflection Paper on the Deepening of the Economic and Monetary Union of 2017. The outbreak of the Covid-19 emergency does not seem to have induced a radical rethinking of this strategy, at least for the moment.

EU's strategy seems to require member countries to modify their institutional framework to resemble the best performing European economies. Despite official statements, many believe that many European countries, especially those of the South, should move towards more efficient institutional frameworks, for example, those of the North. This interpretation lends itself to the opposition of the core and peripheral countries. The latter would be invited to improve their economic performance by imitating the core countries. As commented by De Ville and Vermeiren $(2016$, p.1) the euro area promotes an export-led recovery and growth strategy: "the crisis-ridden member states in the south are instructed to improve their cost competitiveness in order to accumulate export surpluses with which to repay their debt. Emerging economies as the global growth engines of the coming decades are identified as the markets that should absorb these trade surpluses". 
With the European sovereign debt crisis, the debate around the European integration process became increasingly relevant. According to some scholars, the role of institutional variety has been poorly considered by European institutions, and the pressure towards structural reforms almost seems to exchange institutional variety for inefficiency. As confirmed by Nölke (2016, p.152), the shift towards economic frameworks in which the market mechanism dominates is "the blueprint of the Troika reforms". According to Hancké (2012) and Hassel (2014), the sovereign debt crisis of the Eurozone is the results mainly of the combination of two factors: the EMU architecture, which implies a common monetary policy but national fiscal policies, and the coexistence of different types of capitalist models within Eurozone. Indeed, during the economic integration process, it has been undervalued that countries with different varieties of capitalism tend to operate different growth models, are characterized by different inflationary growth regimes, and adapt and react differently to policies and shocks. EMU architecture amplified imbalances through pro-cyclical effects. Hall $(\underline{2018, p .25)}$ emphasises that despite it is true that Mediterranean market economies can no longer operate their domestic demand-led growth model, the ongoing economic experiment aimed to force them to change may end up with "growth models without growth, which will ultimately threaten the very existence of the monetary union". Nölke (2016, p.152) confirms that, anyway, the "institutional complementarities" needed for a similar shift are extremely difficult to be obtained.

The Eurozone crisis and its imbalances cannot be overcome without addressing the deflationary bias produced by the presence of different inflationary growth regimes within EMU. Nölke (2016, p.156) claims that it is very difficult if not impossible for a Mediterranean economy to switch to a continental market economy and claims drastically that according to a significant strand of the comparative capitalism literature, "the best option seems to be some kind of institutional reform of the Euro-system that would give back Southern economies the option to devalue their currencies and to regain an independent monetary policy".

Most VoC theory scholars seem to conclude that an economic convergence based on institutional convergence is undesirable and probably impossible for the Eurozone. Along with $\mathrm{VoC}$ theory, other approaches that take important factors neglected in $\mathrm{VoC}$ theory into consideration (such as the role of capital accumulation, financialization and national governments interventions) came to similar conclusions. For example, in the Marxian perspective "the varieties of capitalism arise from the specificity of the social processes and places that are integrated as part of a wider social system from the very strategies that social agents in these places undertake to expand their scale of action, thereby creating encompassing social structures that take the forms of the law of value and the imperatives of capital accumulation". Consequently, "national and local dynamics of capitalist development are always a process of combined and uneven development in a world market" (Albo, 2005, p.243).

The international crisis of 2008 seems to have further reinforced the need to take into consideration the dynamics of capitalism, its tendency to endogenously generate recurring crises, the expansion of the financial 
sector, the weakness of the working class, the role of internationalization. All factors that according to Heyes et al. (2012) the VoC theory underestimated. In their analysis, however, these authors recognize that, although there is a certain influence of neoliberalism on different models of capitalism, "this is not to argue that economies are converging on a single model of neoliberalism" (Heyes et al., 2012; pp.235-236). As Streeck observes (2010, p. 39), also the concept of variegated capitalism "has been put forward in explicit criticism of the VoC approach, not in an attempt to deny differences, but in order to place them in a context of economic and political interdependence. Conceiving of capitalism as a more or less integrated global system must not, of course, be taken to imply an equally integrated global regime of economic governance, let alone of political government".

There are no convincing reasons to affirm that institutional convergence is necessary for the long-term survival of the Eurozone. As claimed by the motto united in diversity, institutional variety is a precious resource, and it is not a threat to European prosperity. Indeed, "there is increasing recognition in the economics literature that high-quality institutions can take a multitude of forms and that economic convergence need not necessarily entail convergence in institutional forms" (Rodrik, 2007, p.52). Eurozone soundness depends, among other things, also on member countries' ability to make their institutional and economic frameworks coexist. Given that, as evidenced by $\mathrm{VoC}$ theory analysis, each member country presents idiosyncratic institutions, each of them can achieve similar efficient, stable and sustainable outcomes, although in different idiosyncratic ways, and avoiding negative spillovers. This implies that institutional variety can become the tool that allows understanding how to calibrate the various national policies so that each member country can converge towards an efficient and stable path of development. This analysis seems coherent with Hall (2018, p.25), who suggests that "there is more than one route to economic prosperity, and finding a successful national path requires adapting social and economic policies to the institutional conditions specific to each type of political economy".

European institutions need to be more flexible and focus on assessing the quality of national results rather than on procedures. To do this, they must have tools capable of assessing the actual economic, political, and social situation of each member country and identifying inefficiencies and externalities within their respective institutional frameworks. The Eb assumes that the institutional variety of the Eurozone should be preserved and that the various economic-institutional frameworks can coexist. It aims to help countries ensure stability and soundness by identifying inefficiencies and externalities that prevents member country to make their economic, political, and social institution work properly. 


\section{TOWARDS A EUROPEAN BENCHMARK}

The purpose of the Eb is to share a new common vision on how to carry on the European project. A basic starting point is that European institutions' policies should have a more flexible approach focalizing on national outcomes quality instead of on procedures and thresholds, with care for the mutual compatibility and the positive spillovers of these outcomes. The final aim is not the convergence towards a particular economic model to be considered as the benchmark. As a consequence, no structural reforms aimed to change the institutional framework of a country can be drawn from the Eb. Indeed, each member country should be free to pursue the shared outcomes in the most effective way under the constrain of avoiding negative spillovers.

\subsection{European benchmark legitimacy}

The Eb draws on its legitimacy in the European treaties' principles. This type of legitimation is important because the European treaties are the result of the democratic and voluntary approval of the member countries and thus those treaties are entitled to bind their decisions. It must be admitted that EU treaties show a disproportionate focus on fiscal discipline and cost-saving structural reforms aimed to promote competitiveness. The strong emphasis on short-run goals, especially since the financial crisis, has been partially justified by the urgency to guarantee the Eurozone survival. However, it is out of doubt that European treaties promote also political and social goals, despite the presence of some non-economic dimensions within some EU Treaties seems to be sometimes a pure formality. The Maastricht Treaty (MT) aims to encourage member countries to converge towards similar economic performance through price stability, sound public finances and structural reforms. Compatibly with these objectives, the MT aims to promote full employment and balanced and sustainable economic and social progress.

Lisbon Treaty (LT) article 21 cites among the "principles which have inspired its own creation (of the Union)" the principle of solidarity. LT, article 9, states that "the Union shall observe the principle of the equality of its citizens, who shall receive equal attention from its institutions, bodies, offices and agencies". Chapter 3 of the EU Charter of Fundamental Rights is on equality; article 20 states equality before the law. It is important to remember that:

In the Lisbon Treaty, EU countries have subscribed to the goal of establishing competitive social market economies that regard social policies as means of securing social justice, social protection and correcting where the market produces negative externalities. Social policies are hence complementary to economic policies, with the investment in human capital and services allowing citizens to participate in the economy and society to their full potential (Social Protection Committee and the European Commission Services, 2015, p.6). 
With the Lisbon Treaty, these principles become particularly important because they also contribute to the design of the accession criteria for potential new member countries. The accession criteria, or Copenhagen Criteria, group together principles and measures of different nature. They also provide for the presence of political criteria aimed at ensuring that new member countries guarantee human rights, the rule of law, democracy, and respect for minorities; economic criteria aimed at ensuring efficient and competitive markets and finally criteria aimed at ensuring member countries' ability to fulfil membership obligations as defined in the acquis communautaire. Chapters 26 and 28 of the acquis communautaire deals with education, culture, consumer, and health protection. The chapter 19 of the acquis in the social field includes minimum standards in the areas of labour law, equality, health, and safety at work and anti-discrimination. The socalled social chapter of MT disciplines the conditions of workers while the LT, article 3, explicitly states that the Union "shall combat social exclusion and discrimination and shall promote social justice and protection". LT, article 3, states that the Union "shall work for the sustainable development [...] aiming at full employment and social progress, and a high level of protection and improvement of the quality of the environment". The chapter 27 of the acquis deals with the environment. All this seems to confirm that, despite all, the EU treaties and their declared purposes go beyond a simple economic dimension but consider also the social and political one.

\subsection{European benchmark theoretical framework}

The Eb allows evaluating the economic, political, and social performance of each member country and their distance from the benchmark. The benchmark can be defined as the situation in which the institutions of a member country are made to work at their best, so as to achieve a situation capable of guaranteeing stability, solidity and development. This benchmark definition recognizes that a country's institutional framework is an important factor in explaining a country's economic structure and its social, economic, and political performance. The $\mathrm{Eb}$ is based on the identification of pillars. The identification of the pillars is partly inspired by the influential Padoa-Schioppa report (Padoa-Schioppa, 1987), developed by a study group appointed by the Commission of the European Communities in 1987. This report is relevant for our Eb because it clearly identified the conditions that would allow the future monetary union to survive in the long run. In the report is claimed that the 4 freedoms of single markets (freedom of movement of people, services, goods, and capital) were not compatible with floating exchange rates and thus a monetary union was necessary. After this report, the idea of a single currency for the EU has been considered seriously. But most have forgotten the conditions needed for the survival of the future monetary union that the study group summarised in 4 criteria: efficiency, stability, equity, and growth. Efficiency is the ability of competitive markets to allocate resources in an efficient way. Once efficiency is reached, macroeconomic stability can be obtained through monetary stability. But the report underlines that: 
Two further elements must be added: an equitable distribution of the gains in economic welfare, and actual growth performance. Neither of them is adequately assured as of now. Without them, the Community's system would be likely to falter. A successful strategy will therefore require also an adequate mechanism to aid structural change in regions and avoid distributive inequities and preparedness to support the growth process through macroeconomic policy. Agreement on these four points together should, in the Group's judgement, be the basis of the long-term 'social contract' between the Community and all its Member States (PadoaSchioppa, 1987, pp.4-5).

Well before the crisis, the report recognized the "serious risks of aggravated regional imbalance in the course of market liberalization" (Padoa-Schioppa, 1987, p.4) and the importance of equity for the survival of the long-term social contract at the base of the EU. The criteria mentioned in the report focus on the economic dimension, although they also show that they are sensitive to political and social implications. Consequently, starting from this report, other criteria have been added, because the Eb includes in the analysis not only the economic but also the political and social dimensions. Therefore, the Eb has been conceived as a framework in which the following 7 criteria are present: efficiency and effectiveness, stability, equity and equality, growth and development.

The choice of these 7 criteria can be traced to various theoretical sources. Efficiency, i.e., the measurable maximum result obtained from the use of a given amount of resources at the minimum possible cost, is widely considered insufficient to assess the performance of markets and institutions. Indeed, it is important also to assess the quality of the results and their consistency with the objectives. As a consequence, it is the case to consider also effectiveness, which can be defined as the capability of pursuing and implementing an intended or expected result, such as the desired output (see for example Mandl et al., 2008, where both efficiency and effectiveness are considered with reference to public spending).

Equity is mostly an economic concept that responds to the need to face the problem of resource distribution and business fairness based on the equality of rights and opportunities. Consequently, a clear distinction should be made between equity and equality. From an economic point of view, economic equity does not prevent more productive agents to be rewarded properly; from a political point of view, all agents should be considered exactly in the same way and for this reason, is more proper to talk about political equality. Growth is a concept strongly related to the economic dimension while development is a dimension that broadens the perspective by considering structural change and political and social implications, a more "normative concept" that allows considering a qualitative perspective (Carruthers and Babb, 2000, p.145). For this reason, growth has been associated only with the economic dimension, while development to the political and sociological dimensions. 


\subsection{The pillars of the benchmark}

The combination of the 7 criteria with the 3 dimensions produce 15 pillars that will be considered in our analysis as the backbone of the Eb. This is because some criteria can be combined with some dimensions but not with others. As previously explained, equality is a criterion that can be combined with the political dimension, while equity fits the social and economic dimensions. The development allows investigating the social and political dimensions while the growth criterion focalizes on the economic dimension. The pillars are summarised in Figure 1 made by author, where the benchmark is a framework in which the criteria (i.e., efficiency, effectiveness, stability, equity and equality, growth, and development) are analysed according to the economic, political, and social dimensions.

Each pillar can be associated with a definition for the construction of a sound theoretical background. Indeed, the purpose of these pillars is precisely to separate economic, political, and social factors. This should allow to distinguish the roles and responsibilities of each institution and therefore to clarify how and where to intervene to remove inefficiencies and externalities. Obviously, our definitions are not exempt from possible discussions and improvements. A critical point is certainly that it is probably not possible to completely separate economic factors, from social and political ones; at the same time, it is difficult to separate interconnected concepts such as efficiency, effectiveness, growth, development, equity, equality and stability.

Figure 1: The pillars of the benchmark

\begin{tabular}{|l|l|l|l|}
\hline PILLARS & Economic Dimension & Political Dimension & Social Dimension \\
\hline Efficiency & economic efficiency & political efficiency & social efficiency \\
\hline Effectiveness & economic effectiveness & political effectiveness & social effectiveness \\
\hline Stability & economic stability & political stability & social stability \\
\hline Equity/Equality & economic equity & political equality & social equity \\
\hline Growth/Development & economic growth & political development & social development \\
\hline
\end{tabular}

The pillars are by their nature strictly interconnected and many concepts expressed in these definitions are multidisciplinary. Despite this, an effort will be made in order to offer quite independent definitions.

1) Economic efficiency: resources in the goods, labour and financial markets are used and allocated in an optimal way and output is produced and traded at the lowest cost. The efficiency of all goods markets implies the possibility for companies to operate in a competitive environment that enables consumers to buy goods produced through an eco-sustainable production at the lowest price. This implies contained inflation and efficient use of resources. Labour market efficiency involves not only the commitment to achieve the full employment of human resources but also the possibility for workers to obtain a job 
consistent with their attitudes and to work in their best-performing age. This implies contained unemployment. Financial market efficiency implies the ability to allocate resources minimizing transactional costs and offer financial instruments and services in a competitive environment.

2) Economic effectiveness: capacity of goods, labour and financial markets to promote and facilitate the achievement of the economic agents' objectives to social advantage. Goods market effectiveness implies the ability of sound companies to respond promptly to the needs of the demand through the offer of quality products. Labour market effectiveness allows households to get a stable source of livelihood through work and at the same time allows companies to find a qualified and professional labour force. Financial market effectiveness implies the ability to mobilize financial resources through investments in the real economy and with the aim to involve also those economic agents with limited access to financing (typically small and medium-sized enterprises, SMEs).

3) Economic stability: economic soundness through stable financial markets and solid banking system, limited economic vulnerability and credible economic policies. This definition of economic stability refers to the conditions that allow the economy to follow a predictable long-term trend. This is possible if economic policies are credible and aimed to protect national interests, financial markets and the banking system are not a source of instability and, finally if the economic vulnerability is limited. Economic vulnerability means an excessive sensitivity to decisions by external economic agents. Foreign dependency, external ownership or control, dependence on external sources can all become sources of economic vulnerability.

4) Economic equity: equity in the distribution of income, economic opportunities, and fairness in business. Economic equity implies a fair distribution of resources between all the economic agents that have participated in the economic activity proportionally to their contribution and the access to the same economic opportunities according to the attitudes and skills of each economic agent. Fairness in business implies that all economic agents can operate within a transparent and fair environment, in which the rights of all, including minorities, are respected.

5) Economic growth: the increase in the amount and quality of goods and services produced also through technical progress. It is important to consider both supply-side and demand-side growth sources and the role of government in promoting growth.

6) Political efficiency: the ability of the political institutions of the state (the trias politica: legislative, executive and judicial system) to create, approve and enforce only the necessary laws and solve conflicts promptly, with rapid and fair procedures, minimizing social, economic and bureaucratic costs. Political efficiency implies legislative, executive and judiciary efficiency. Legislative efficiency is the ability of 
the government to create, approve and apply quickly the laws strictly necessary for the prosperity of the country. Executive efficiency is the ability of the public administration to promptly carry out its management functions minimizing the bureaucratic costs for the community. Judiciary efficiency is the ability of the judicial system to apply laws through rapid and fair procedures, minimizing social costs. Political efficiency implies in general coordination, competence, communication skills and transparency with citizens and other institutions.

7) Political effectiveness: the ability of political institutions to effectively influence the behaviour of agents by announcing, creating, approving and enforcing laws and procedures resulting from shared decisions that meet the economic and social needs of the country. Political effectiveness implies legislative, executive and judiciary effectiveness. Legislative effectiveness is the ability of the government to create, approve and apply laws that result to be shared, useful and important for the progress of the country. Executive effectiveness is the ability of the public administration to exercise its functions so that to meet the needs and the rights of citizens by limiting the negative impacts of bureaucracy. Judiciary effectiveness is the ability of the judicial system to apply laws and resolve conflicts with justice so that to meet the needs and rights of citizens. Political effectiveness implies in general reliability and confidence towards those institutions.

8) Political stability: stability of the political system as a result of the trust of the electorate, the political class and the other institutions in the political regime and in the mechanisms and laws that regulate the management of power. Political stability implies stability in the political system, government and electoral body. Antipolitical currents, disagreements between institutions, terrorist groups and bad relations with neighbouring countries can threaten the stability of the political system. Government stability implies political equilibrium and predictable politics which ensure durable governments. Electoral body stability implies the participation of the electorate in political life, trust in the political system, political class and respect for institutions. Political stability implies in general national cohesion and power legitimacy.

9) Political equality: citizens are equals before the law and all the political institutions of the state. It implies the absence of corruption, favouritism, cronyism, and discrimination and implies also the independence and impartiality of the institutions. It implies legislative, executive and judiciary equality. All citizens are equal before the government, the public administration, and the judicial system. The laws of the government, the functions of the public administration and the procedures and sentences of the judicial system must respect the Constitution and the rights of all citizens.

10) Political development: a continuous process of rationalization and qualitative improvement of the structures, procedures and outputs of the political institutions of the state. It implies legislative, 
executive and judiciary development. It requires the government, the public administration, and the judicial system the ability to cooperate and implement reforms to adapt quickly to the needs of society coherently with a long-term strategic vision.

11) Social efficiency: the ability of the institutions to pursue social utility by offering quality services and structures at the lowest economic, bureaucratic, and social transaction cost. The sectors of greater social utility are the health system, educational system, training and research system and infrastructures.

12) Social effectiveness: the capability to pursue social goals, the capacity of solving negative externalities produced by market inefficiencies, and the ability to produce public goods and promote quality improvements to meet the needs of the citizen. The sectors of greater social utility are the health system, educational system, training and research system and infrastructures. Health system effectiveness implies the ability to ensure adequate health coverage and eradicate epidemics and diseases. Educational, training and research system effectiveness is the ability to provide the new generations with good cultural background and adequate skills able to meet the needs of the labour market. Infrastructure effectiveness implies quality, useful and reliable infrastructures, able to meet the needs of all citizens and the production system. Social effectiveness implies in general trust and satisfaction for all citizens.

13) Social stability: effectively pursuing social cohesion and properly managing and solving social conflicts by means of governmentally formalized, regulated and enforced laws, rules, and norms for social relations (Gubin et al., 1993). Social stability implies public security and the absence of social or identity-based conflicts. This means public order and protection of persons and property from threats such as thefts, physical aggression, and violence of various types. It includes the fight against organized crime and against any type of illicit trade. Social stability implies also the lack of conflicts within social classes or different ethnic-religious groups.

14) Social equity: impartiality, fairness and justice in the social and labour relations. Social equity implies social inclusion, social responsibility and equal social opportunities. Social inclusion is the presence of an efficient and effective assistance and social security system aimed at ensuring adequate standards of living and working and protection of vulnerable people. All this can be achieved through a welfare system. Social responsibility is the degree of awareness at the level of individual citizens of the importance of the respect of the rules, the civic sense and the culture of legality. Equal social opportunities as the elimination of all sources of discrimination and the presence of measures able to guarantee the respect of human and social rights for promoting full integration and participation in social life. 
15) Social development: a process of planned or spontaneous social change designed to promote the wellbeing of the population (Midgley, 1995, p.25) and its human and cultural development. Social development implies human, cultural and well-being development. Human development implies the improvement of the quality of civil coexistence: cooperation, solidarity, volunteering and ethical behaviour of citizens and organizations can be indicators of this development that brings citizens to share common objectives and to respect the environment. Cultural development implies the widespread of technology, the sharing of ideas and the improvement of the quantity and quality of products of every type of art or expression of human creativity. The care for the cultural, historical, and natural heritage is also a sign of this development. Well-being development implies the improvement of every citizen's quality of life and prospects. The collective well-being can be expressed in a progressive decline in selfdestructive tendencies and an improvement of sociality.

\subsection{Some crosscutting concepts}

There are some concepts that are common to more pillars. These crosscutting concepts are social capital, sovereign debt sustainability and structural change. Social capital is a controversial but important concept for economics and social sciences. It can be defined as the "features of social organization, such as network, norms, and trust, that facilitate coordination and cooperation for mutual benefit" (Putnam, 1993, p.36). All definitions of social capital "link the economic, social, and political spheres [and] focus on relationships among economic agents and how the formal or informal organization of those can improve the efficiency of economic activities" (Grootaert, 1998, p.4). The pillars of the benchmark incorporate many elements that are the basis of the definition of social capital. This implies that social capital is a crosscutting concept in our $\mathrm{Eb}$.

It may come as a surprise that the role of sovereign debt sustainability has not been mentioned in the economic pillars. European convergence criteria are based on rules that discipline, among other things, the levels of government budget deficit and the government debt-to-GDP ratio (i.e., the limits of 3\% for the public Deficit/GDP ratio and 60\% for the Public Debt/GDP ratio). Unfortunately, these rules and limits are controversial and lack robust and widespread theoretical support. As claimed by Neck and Sturm $(2008, p .1)$ "although the sustainability of public finances has been discussed for more than a century now, it is still an imprecise concept. While it is intuitively clear that a sustainable policy must be such as to eventually prevent bankruptcy, there is no generally agreed upon definition of what precisely constitutes a sustainable debt position". Certainly, a high level of public indebtedness within the European Union is a factor that nowadays increases economic vulnerability through negative effects on the creditworthiness of sovereign bonds. But what is often underestimated is the importance of the quality of public indebtedness, the circumstances that can lead to its increase and the role of public investment. Unfortunately, "cutting public investment has been a common response of European governments during the crisis, despite various studies highlighting the 
detrimental effects on growth" (Zuleeg and Schneider, 2015, p.1). According to Zuleeg and Schneider (2015, p.3) "the importance of social and other productive public investment should be reflected in the SGP [Stability and Growth Pact]. This could be achieved by introducing a Golden Rule, enabling governments over the economic cycle - to borrow only to invest and not to fund current spending". This point of view is shared also by other scholars such as Truger (2015) who support the so-called golden rule of public investment. It is not the purpose of this section to carry on this debate. What matters, for our purposes, is that the quality of public budget management depends on different factors such as the efficiency, effectiveness, and equity with which the public sphere manages its resources, and the stability of markets and institutions. All these factors are considered in the pillars of the Eb.

Structural change is a long-term dynamic process able to involve radical changes in the socio-economic structure, the markets, and the institutions. It is a condition for growth that assumes great importance within development economics. It can be claimed that "industrialization is then the central process of structural change" (Syrquin, 1988, p.206). It is evident that, within the Eb, structural change is present in more pillars, and can be perceived in the dynamics of European member countries towards the Eb and in the way in which the same Eb can evolve towards better standards.

\section{CONCLUSIONS}

The Eurozone experienced troubles since the beginning of its integration process. European economic and institutional variety prevented Eurozone to become a fiscal and political union. During the European integration process economic, institutional, and cultural variety persisted. The asymmetric architecture of EMU presented different weaknesses. A key problem is that the unique monetary policy of the ECB provokes asymmetric shocks among heterogeneous member countries amplifying macroeconomic imbalances. With the financial crisis in 2007 , the weaker member countries became particularly vulnerable to financial market turmoil with dramatic consequences. Surely, greater integration cannot be achieved without a rethinking of the European integration project.

The crisis does not indicate the need to promote institutional convergence within the Eurozone. Indeed, institutional variety is a resource for the EU and many scholars are convinced that high-quality institutions are compatible with many institutional frameworks. Each member country presents idiosyncratic institutions. The objective must be to make the various economic-institutional frameworks coexist within the Eurozone, helping member countries to achieve a situation that guarantees stability and development. These goals can be achieved in different idiosyncratic ways, avoiding negative spillovers. 
European institutions need to be more flexible and focus on assessing the quality of national results rather than on procedures. To do this, they must have tools capable of assessing the actual economic, political and social situation of each member country and identifying inefficiencies and externalities within their respective institutional frameworks.

The Eb, inspired by European treaties, represents a new tool for a correct evaluation of the economic, social, and political performance of the European member countries. Its purpose is to help member countries to identify inefficiencies in terms of market, state and social failures and externalities inside economic, social and political institutions. At the base of the $\mathrm{Eb}$, there is the identification of 15 pillars. The framework that emerges from these pillars does not aim to identify a particular economic-institutional structure as the best but to obtain the maximum performance from whatever type of particular market structure. The pillars allow to identify for each EU country the strengths and weaknesses of their economic, political, and social institutions and to measure their distance from the benchmark. Surely, the Eb can fully show its potential through an empirical study, which will associate to each pillar a proper set of indicators that would allow quantifying the distance of each country from the Eb. Starting from the results of similar empirical research, it will be possible to identify the policies and reforms that each country should implement to shorten its distance from the $\mathrm{Eb}$, what the EU should do to make its policies more effective, and the influence of ECB decisions on the performance of the member countries. These investigations represent object of subsequent research.

FUNDING: The authors did not receive any external funding.

CONFLICT OF INTEREST: The authors declare no conflict of interest.

\section{REFERENCES}

1. Albo, G. (2005). Contesting the 'New Capitalism'. Centre for Civil Society Research Report, No. 39. Volume 2. York University, Department of Political Science. Available at: https://ccs.ukzn.ac.za/files/CCS RREPORTS2_REPORT39.pdf

2. Alesina, A., G. Tabellini, and F. Trebbi (2017). Is Europe an optimal political area? Technical report, CESifo Working Paper, No. 6469, Center for Economic Studies and Ifo Institute (CESifo), Munich. DOI 10.3386/w23325. Available at: https://www.cesifo.org/en/publikationen/2017/working-paper/europe-optimal-political-area 
3. Beck, H. and A. Prinz (2012). The trilemma of a monetary union: Another impossible trinity. Intereconomics 47(1), 39-43. DOI: https://doi.org/10.1007/s10272-012-0404-0

4. Blaschke, S. (2000). Union density and European integration: diverging convergence. European Journal of Industrial Relations 6(2), 217-237. DOI: https://doi.org/10.1177\%2F095968010062006

5. Calmfors, L. and J. Driffill (1988). Bargaining structure, corporatism and macroeconomic performance. Economic Policy 3(6), 13-47. DOI: https://doi.org/10.2307/1344503

6. Carruthers, B. G. and S. L. Babb (2000). Economy/Society: Markets, Meanings, and Social Structure. Thousand Oaks (CA): Pine Forge Press. ISBN 0761986855. Available at: https://books.google.es/books?id=3mwwzZVzVSIC\&lpg=PP9\&ots=sB6ugQ9PHB\&dq=Carruther s\%2C\%20B.\%20G.\%20and\%20S.\%20L.\%20Babb\%20(2000).\%20Economy\%2Fsociety \%3A\%20 Markets\%2C\%20meanings\%2C\%20and\%20social\%20structure.\%20Thousand\%20Oaks\%20(CA) \%3A\%20Pine $\% 20$ Forge $\% 20$ Press.\&lr\&pg $=\mathrm{PP} 6 \# \mathrm{v}=$ onepage\&q\&f=false

7. Cernat, L. (2006). Europeanization, varieties of capitalism and economic performance in Central and Eastern Europe. Houndmills: Palgrave Macmillan. ISBN 978-0-230-50168-3. DOI: $10.1057 / 9780230501683$

8. Crespy, A. and G. Menz (2015). Commission Entrepreneurship and the Debasing of Social Europe Before and After the Eurocrisis. Journal of Common Market Studies 53(4), 753-768. DOI: https://doi.org/10.1111/jems.12241

9. D’Erman, V., J. Haas, D. F. Schulz, and A. Verdun (2019). Measuring Economic Reform Recommendations under the European Semester: 'One Size Fits All' or Tailoring to Member States? Journal of Contemporary European Research 15(2), 194-211. Available at: https://hdl.handle.net/1887/80302

10. Dan, H. (2014). The euro zone-between fiscal heterogeneity and monetary unity. Transylvanian Review of Administrative Sciences, 43, 68-84. Available at: https://ssrn.com/abstract=2654649

11. De Grauwe, P. (2013). Design Failures in the Eurozone: Can they be fixed? LEQS Paper, No. 57. DOI: https://papers.ssrn.com/sol3/papers.cfm?abstract id=2215762

12. De Ville, F. and M. Vermeiren (2016). Rising Powers and Economic Crisis in the Euro Area. London: Palgrave Macmillan. ISBN: 9781137514394. DOI 10.1057/978-1-137-51440-0

13. Dyson, K. (2000). The Politics of the Euro-Zone: Stability or Breakdown? Oxford: Oxford University Press. Print ISBN-13: 9780199241651. DOI:10.1093/0199241651.001.0001

14. Dyson, K., and I. Maes (2016). Architects of the Euro: Intellectuals in the Making of European Monetary Union. Oxford: Oxford University Press. Print ISBN-13: 9780198735915. DOI:10.1093/acprof:oso/9780198735915.001.0001

15. Follesdal, A., and S. Hix (2006). Why there is a democratic deficit in the EU: A response to Majone and Moravcsik. Journal of Common Market Studies, 44(3), 533-562. DOI:

https://doi.org/10.1111/j.1468-5965.2006.00650.x 
16. Frankel, J. A. and A. K. Rose (1998). The endogeneity of the optimum currency area criteria. The Economic Journal 108(449), 1009-1025. DOI: https://doi.org/10.1111/1468-0297.00327

17. Grootaert, C. (1998). Social capital: the missing link? Social Capital Initiative. Working Paper No. 3. Available at: https://silo.tips/download/social-capital-the-missing-link

18. Gubin, O. I., M. M. Young, G. A. Osipov, and N. Kostioutchenko (1993). Social Control Versus Social Stability: A Conceptualization of Contradictory Goals and Hybrid Outcomes on Ethnic Relations, Consumer Satisfaction, and Entrepreneurship in the Former USSR. Advances in Consumer Research 20, 89-96. Available at: https://www.acrwebsite.org/volumes/7420

19. Hall, P. A. (2018). Varieties of capitalism in light of the euro crisis. Journal of European Public Policy 25(1), 7-30. DOI: http://dx.doi.org/10.1080/13501763.2017.1310278

20. Hall, P. A. and D. Soskice (2001). Varieties of Capitalism. The Institutional Foundations of Comparative Advantage. Oxford: Oxford University Press. Print ISBN-13: 9780199247752. DOI:10.1093/0199247757.001.0001

21. Hancké, B. (2012). Worlds apart? Labour Unions, Wages and Monetary Integration in Continental Europe. IHS Political Science Series, No.128. Available at: http://aei.pitt.edu/33636/

22. Hassel, A. (2014). Adjustments in the Eurozone: Varieties of Capitalism and the Crisis in Southern Europe. LEQS Paper, No.76. Available at: https://www.lse.ac.uk/europeaninstitute/Assets/Documents/LEQS-Discussion-Papers/LEQSPaper76.pdf

23. Heyes, J., P. Lewis, and I. Clark (2012). Varieties of capitalism, neoliberalism and the economic crisis of 2008-?. Industrial Relations Journal, 43(3), 222-241. Available at: http://irep.ntu.ac.uk/id/eprint/35062/1/Clark_12588.pdf

24. Iversen, T. and D. Soskice (2013). A structural-institutional explanation of the eurozone crisis. Unpublished manuscript. Cambridge (MA): Harvard University, Department of Government. Available at: http://www.people.fas.harvard.edu/ iversen/PDFfiles/Iversen\&Soskice 2017.pdf

25. Kaldor, N. (1980). Further essays on applied economics. In Collected Economic Essays of Nicholas Kaldor, Vol.6, Ch.12, pp. 187-220. London: Wiley.

26. Maes, I. (2002). Economic Thought and the Making of European Monetary Union. Cheltenham (UK): Edward Elgar Publishing.

27. Mandl, U., A. Dierx, and F. Ilzkovitz (2008). The efficiency and effectiveness of public spending. Economic Papers. European Commission, Directorate-General for Economic and Financial Affairs, Brussels, No. 301. ISBN 9789279082269. Available at: https://searchworks.stanford.edu/view/9370365

28. Marsh, D. (2009). The euro: the politics of the new global currency. New Haven (CT): Yale University Press. ISBN: 9780300164008. Available at: https://yalebooks.yale.edu/book/9780300164008/euro 
29. McKinnon, R. (1963). Optimum currency areas. The American Economic Review, 53(4), 717-725. Available at: https://www.jstor.org/stable/1811021

30. Midgley, J. (1995). Social development: The developmental perspective in social welfare. Thousand Oaks (CA): Sage. ISBN 0803977735. Available at:

https://books.google.es/books?id=t8BL-

3 x 5 YC\&lpg=PP11\&ots=Nq4T6PzjJS\&dq=Midgley\%2C\%20J.\%20(1995).\%20Social\%20devel opment $\% 3 \mathrm{~A} \% 20 \mathrm{The} \% 20$ developmental $\% 20$ perspective $\% 20 \mathrm{in} \% 20$ social $\% 20$ welfare. $\% 20$ Thousan $\mathrm{d} \% 200 a k s \% 20(\mathrm{CA}) \% 3 \mathrm{~A} \% 20$ Sage.\&lr\&pg=PP6\#v=onepage\&q=Midgley,\%20J.\%20(1995).\%20S ocial\%20development:\%20The $\% 20$ developmental $\% 20$ perspective $\% 20 \mathrm{in} \% 20$ social $\% 20$ welfare. $\%$ 20Thousand $\% 20$ Oaks $\% 20(\mathrm{CA}): \% 20$ Sage.\&f=false

31. Mundell, R. (1961). A theory of optimum currency areas. The American Economic Review, 51(4), 657-665. Available at: https://www.aeaweb.org/aer/top20/51.4.657-665.pdf

32. Neck, R. and J.-E. Sturm (2008). (Eds.) Sustainability of public debt. Cambridge (MA): MIT Press. ISBN: 9780262140980 . Available at: $\underline{\text { https://mitpress.mit.edu/books/sustainability-public- }}$ debt

33. Nölke, A. (2016). Economic causes of the Eurozone crisis: the analytical contribution of Comparative Capitalism. Socio-Economic Review 14(1), 141-161. DOI: https://doi.org/10.1093/ser/mwv031

34. Padoa-Schioppa, T. (1987). Efficiency, stability, and equity: a strategy for the evolution of the economic system of the European community: a report. New York: Oxford University Press.

35. Putnam, R. D. (1993). The prosperous community-social capital and public life. American Prospect 13, 35-42. Available at: https://www.semanticscholar.org/paper/The-ProsperousCommunity\%3A-Social-Capital-and-PublicPutnam/7ca2ff64d7db151775ed4ff002754157189ddca0

36. Rodrik, D. (2007). One Economics, Many Recipes: Globalization, Institutions, and Economic Growth. Princeton: Princeton University Press. DOI: https://doi.org/10.1515/9781400829354

37. Scharpf, F. W. (2011). Monetary union, fiscal crisis and the pre-emption of democracy. Zeitschrift für Staats- und Europawissenschaften (ZSE)/Journal for Comparative Government and European Policy 9(2), 163-198. Available at: https://www.jstor.org/stable/24237162

38. Schönfelder, N. and H. Wagner (2019). Institutional convergence in Europe. Economics: The Open-Access, Open-Assessment E-Journal 13(3), 1-23. DOI: https://doi.org/10.5018/economicsejournal.ja.2019-3

39. Social Protection Committee and the European Commission Services (2015). Social Protection Systems in the EU: Financing Arrangements and the Effectiveness and Efficiency of Resource Allocation. Luxembourg: Publications Office of the European Union. Available at: https://data.europa.eu/doi/10.2767/983538 
40. Streeck, W. (1997). German capitalism: Does it exist? Can it survive? In C. Crouch and W. Streeck (Eds.), Political Economy of Modern Capitalism: Mapping Convergence and Diversity, pp. 33-54. London: Sage.

41. Streeck, W. (2010). E pluribus unum? Varieties and commonalities of capitalism. MPIfG Discussion Paper 10/ 12. Max Planck Institute for the Study of Societies, Cologne. Available at: https://www.mpifg.de/pu/mpifg dp/dp10-12.pdf

42. Syrquin, M. (1988). Patterns of structural change. In H. Chenery and T. N. Srinivasan (Eds.), Handbook of Development Economics, Vol.1, Ch.7, pp.203-273. Amsterdam: Elsevier. ISBN: 9780444703378. Available at: https://www.elsevier.com/books/handbook-of-developmenteconomics/chenery/978-0-444-70337-8

43. Thirion, G. (2017). European Fiscal Union: Economic rationale and design challenges. CEPS Working Document, No.1. Available at: https://www.ceps.eu/ceps-publications/european-fiscalunion-economic-rationale-and-design-challenges/

44. Truger, A. (2015). Implementing the Golden Rule for Public Investment in Europe: Safeguarding Public Investment and Supporting the Recovery. WWWforEurope Policy Paper, No.22. Available at: https://econpapers.repec.org/RePEc:wfo:wstudy:57898

45. Vane, H. R. and C. Mulhearn (2006). Interview with Robert A. Mundell. Journal of Economic Perspectives 20(4), 89-110. DOI: 10.1257/jep.20.4.89

46. Willett, T. D., O. Permpoon, and C. Wihlborg (2010). Endogenous OCA analysis and the early euro experience. The World Economy 33(7), 851-872. DOI: https://doi.org/10.1111/j.14679701.2010.01268.x

47. Windolf, P. (1989). Productivity coalitions and the future of European corporatism. Industrial Relations: A Journal of Economy and Society 28(1), 1-20. DOI: https://doi.org/10.1111/j.1468232X.1989.tb00719.x

48. Zeitlin, J., and B. Vanhercke (2017). Socializing the European Semester: EU social and economic policy coordination in crisis and beyond. Journal of European Public Policy 25(2), 149-174. DOI: https://doi.org/10.1080/13501763.2017.1363269

49. Zuleeg, F. and J. D. Schneider (2015). What role for social investment in the new economic governance of the Eurozone? EPC Policy Brief, 10 November 2015. Available at: http://aei.pitt.edu/69551/1/pub 6086 social investment.pdf 